\title{
Correction: EEG amplitude modulation analysis for semi-automated diagnosis of Alzheimer's disease
}

Tiago H Falk ${ }^{1 *}$, Francisco J Fraga ${ }^{2}$, Lucas Trambaiolli ${ }^{3}$ and Renato Anghinah ${ }^{4}$

\section{Correction}

The article [1] was published without the correct acknowledgements section which can be found below:

The authors would like to acknowledge the financial support from the São Paulo Research Foundation, FAPESP (Fundação de Amparo à Pesquisa de São Paulo), as well as the two reviewers whose insightful comments helped improve the paper.

\footnotetext{
Author details

'Institut National de la Recherche Scientifique, Energy, Materials, and Telecommunications, University of Quebec, Montréal, Quebec, Canada. ${ }^{2}$ Engineering, Modeling and Applied Social Sciences Center, Universidade Federal do ABC, Santo André, Brazil. ${ }^{3}$ Mathematics, Computing and Cognition Center, Universidade Federal do ABC, Santo André, Brazil. ${ }^{4}$ Reference Center of Behavioral Disturbances and Dementia, School of Medicine, Universidade de São Paulo, São Paulo, Brazil.
}

Received: 10 April 2014 Accepted: 10 April 2014

Published: 16 April 2014

\section{References}

1. Falk, TH, Fraga, FJ, Trambaiolli, L, Anghinah, R: EEG amplitude modulation analysis for semi-automated diagnosis of Alzheimer's disease. EURASIP J. Adv. Signal. Process. 2012, 192 (2012).

Submit your manuscript to a SpringerOpen ${ }^{\circ}$ journal and benefit from:

- Convenient online submission

- Rigorous peer review

- Immediate publication on acceptance

- Open access: articles freely available online

- High visibility within the field

- Retaining the copyright to your article

Submit your next manuscript at $>$ springeropen.com 